\title{
研究者ネツト：生命学の試み 学際的システムとして
}

\section{森岡 正博*}

編集部の馬野先生から、いまの私の研究についてな んでも書いてほしいと依頼されてしまった。ちょっと びっくりしたが、尃門の違うす々に向かって何かを書 く機会はけっして多くないので、よろこんでお引き受 けした。だが、何を書いていいのやらいまだによく分 かってない。私の研究テーマは、「生命学」というもの である。生命学というと「生命科学」の一種ですかと 聞かれることが多いが、そういうわけではない。生命 学は、私が 1988 年に提唱した、一種の総命学のことで ある。その後、いろんな紆余曲折があって、しだいに その輪郭が明らかになってきている。

その前に、私自身のことについて語っておいたほう がいいかもしれない。私はそもそも理系と文系の両办 に関心があって、いずれの興味も捨てきれなかった。 大学は理系のコースに進学したが、教養課程を 3 年間 過ごすうちに、理系の独特の狭さが自分に合わなくな って、文系に転じてしまった。私は数学が好きだった し、そのころファジィ論理学などにも興味をもって解 説書を読んでいた記憶がある。理系の狭さといま言つ たが、それは何かというと、对象を解明するときに、 そこに関与する「ファクター」の数をぎりぎりまで切 りつめて解析しようとするその方法論になじめなかっ たのである。たとえば、ある現象を分析するときに、 ほんとうはそういう現象が生じている今日の社会情勢 とか、人々の価值観とか、そういうものが何かの影響 を及ぼしているはずなのに、いわゆる自然科学的アプ ローチというやつは、そういう次元のことを考虑に入 れない。パラメーターを絞ることによって、厳密な数 理的解析の土俵に乗せようとする。

その方法論に有効性があるのは言うまでもないが、 私はいまいちそれに乗れなかった。ある事象に関与し ているファクターの全体を、自分自身で捉えてみたい という願望、それも数理的手法ではなく、むしろ自分 白身の直観によって身体全体で把握したいという願望

* 大拻府立大学 総合科学部

College of Integrated Arts and Sciences, Osaka Prefecture University
が私には強かったのだった。文系に進んでみたが、そ こにはまたそれなりの限界があった。文系は基本的に 文献学を基礎として抢り、現実の事象を㚈イナミック に捉える指向性が少なかった。現実の事象を捉えるも のは社会科学と呼ばれており、そこでは人間の内面性 への洞祭が希薄であった。

このようにして、あちこちをさまよったあげく、も う自分自身で学問の総合をするしかないんではないか と思い始めた。私がいちばん気になっていた「生と死」 「自然」「科学技術」どのトピックスを、ひとつのデ イシプリンからではなく、学際的・総合的に深めてい くための枠組みとして、「生命学」というものを提唱し たわけである。たとえば、私がそれを提唱しはじめた 1980 年代終わりというのは、日本で脳死蔵器移植問題 が国民的議論になっていた時期でもあった。私もまた その議論に参加し、『脳死の人』という本を書いた。だ が、その議論に加わってみてしみじみ感じたのは、脳 死藏器移植が問いかけている問題というのはきわ好 学際的であるにもかかわらず、それをめぐる議論はど うしようもなく専門性の枠にしばられたものでしかな かった、ということだ。移植医の発言は、医学の中の、 移植医療という視点からの発言でしかない。そのほか の側面、たとえばドナーの心理的側面とか、「生とは何 か、死とは何か」という哲学的側面は、まるで頭の中 にないかのようであった。

脳死の議論に加わることで、私は、生命学という学 問の意味がわかりはじめた。生命学は、けっして専䦕 学ではない。生命学というのは、いまここで生きてい る私が、自分自身の問題意識によって、生と死・自然・ 科学などの本質を明らかにしていくところの、「ひとり 学際」的研究活動のことである。だから、これは、学 会を通じて専門的知識を蓄積していく「客観的学間」 とは、また別湖の学問的行為であると言える。以前は、 ここまで大胆に言ってしまっていいのだろうかという 迷いもあったが、いまは吹っ切れてしまったから、こ ういうふうに言う。真の意味で「学際・総合」を追求 
していけば、それは、いまの学問という制度をはみ出 してしまうのは当然なのだ。生命学というのは、その 万向性を指向している。

私が思っているのは、学問の総合ということを達成 するのは、専門家ではなく、素人ではないかというこ とだ。だから、私は、ここ10 年くらい、素人の立場に 站つと公言している。私は専門を持なない。専門を持 たずに大学の教員をしているというめずらしい人間だ。 大阪府立大学総合科学部には、総合研究というめずら しい科目があって、そのディレクタ一のひとりをさせ てもらってきたが、私にいちばん合っているのは総合 研究というような枠組みなのだろうと思う。いずれ総 合研究についても本を望こうと思っている。なかなか 魅力的なテーマである。

ファジィということに引きつけて言えば、生命学は けっこうファジィな学闑である。生と死の問題に白黒 がはっきりと出るわけはない。二值論理の世界ではな く、最低でも多值論理の世界なのだ。それに加えて、 われわれひとりひとりの主観性というものが、大きな 比重を占めることになる。われわれが自分自身の人生 のなかで経験してきたことや、学んできたことを、ど うやて統合化していくかということがテーマのひと つになる。主観性のバイアスを離れた客観的な学問と しての自然科学とは、また異なったパラダイムを指向 している。

生と死を総合的に考えていくわけだから、脳死藏器 移植だけではなく、体外受精や、クローン技術や、地 球環境問題なども考察の対象になる。さらには、われ われの生命力と文明の関係の問題として、現代の教育 が抱える諸問題や、こころのケアなどのテーマもある。 これらの諸問題を互いに関連性を持つものとして考察 していくと、それは、われわれの文明の根本構造をど こまでも深く掘り下げていく試みになっていくのだ。 私は、これらの作業を続けてきた。それは、論理の力 と直観の力をともに最大限まで使って前進していく営 みである。

私はいま自分の研究の発表媒体を、徐々にインター ネットに移行させている。いままでは雑誌や書籍の形 で発表していなが、これからはホームページでそれら を行ない、かつ、私の読者とのコミュニケーションも またホームページトで行なう。すでに、2 年間かけて、
自分のホームページで私が書いた論文やエッセイなど を全文公開してきた。これからは絶版になった著書な どの全文公開も順次試みていく。いずれ、私の全集は、 書籍の形ではなく、ホームページの形で残されていく ことになるだろう。読者とのコミュニケーションも軌 道に乗ってきた。現在、日に250ヒットあるから、こ れからはもう新刊をいきなりホームページ上で公開し てもいいかもしれない。

今年の 2 月から、懸案の英語ホームページも立ち上 げた。ここには、私の書いた英語論文などを公開して あるが、私の日本語書籍も順次英訳して世界に公開市 るつもりである。「生命学」という考え方は、まだ世界 には知られていない。英訳はLife Studies と言う。私 がいままで日本語で行なってきた研究は、世界に公開 してもけっこう反響があると思う。Life Studiesとい う考え方は、おもしろいことに、まだ英諳世界には存 在していない。彼らの賛同を得ることができれば、日 本発の新しい学問のひとつとなることであろう。人文 科学の分野では、著書を海外の大学出版会から英訳し て出版するというのが、従来のやり方であったが、私 はそのようなやり方をとらない。いきなりインターネ ットで英訳を全文公開する。そのほうが時間の節約に なるし、桁違いに多くの人々に見てもらうことができ る。さらに、彼らとのコミュニケーションも可能にな る。英語ぺージを公開してから、すでに私の仕事に興 味を持つ訪問者もあらわれている。

英語を通して、ひとつのムーブメントを起こしてい くためのッールとして、インターネットは可能性に満 ちている。私の「生命学」もまた、それにぴったりの 学問なのである。

*生:命学ホームページ

日本語：http://member.nifty.ne.jp/lifestudies/

英 語: http://homepage 1.nifty.com

[問い合わせ先]

干 599-8531 堺市学園町 1-1

大阪府立大学 総合科学部人間科学科

森岡正博

TEL : 0722-54-2638

FAX : 0722-54-9928

Internet: pbi $01055 @$ nifty.ne.jp 